East Tennessee State University

Digital Commons@ East Tennessee State University

ETSU Faculty Works

Faculty Works

2008

\title{
Connections Through Clubs: Collaboration and Coordination of a Schoolwide Program
}

Wendy Logan

North Windy Ridge School

Janna L. Scarborough

East Tennessee State University, scarboro@etsu.edu

Follow this and additional works at: https://dc.etsu.edu/etsu-works

Part of the Student Counseling and Personnel Services Commons

\section{Citation Information}

Logan, Wendy; and Scarborough, Janna L.. 2008. Connections Through Clubs: Collaboration and Coordination of a Schoolwide Program. Professional School Counseling. Vol.12(2). 157-161. https://doi.org/10.5330/PSC.n.2010-12.157 ISSN: 1096-2409

This Article is brought to you for free and open access by the Faculty Works at Digital Commons @ East Tennessee State University. It has been accepted for inclusion in ETSU Faculty Works by an authorized administrator of Digital Commons @ East Tennessee State University. For more information, please contact digilib@etsu.edu. 


\title{
Connections Through Clubs: Collaboration and Coordination of a Schoolwide Program
}

\author{
Comments \\ This document was published with permission from the publisher. It was originally published in the \\ Professional School Counseling.
}



of a Schoolwide Program

The “Connections Through Clubs" program provides all students with the opportunity to participate in a small-group extracurricular activity and mentoring experience led by school faculty, staff, and community members during the school day throughout the academic year. This schoolwide program was developed in response to identified school needs and as a means to facilitate a strengths-enhancing school environment and to promote the developmental competencies of all students, both of which have been linked to academic and personal success. The purpose of this article is to describe the inception, implementation, and preliminary evaluation of the Connections Through Clubs program. In addition, the school counselor's collaboration, coordination, and advocacy efforts to implement this program are highlighted.

-

he conference room was filled with discouraged and frustrated teachers and administrators. For the first time since our intermediate fifth-andsixth-grade school's development, it appeared we had not made the expected growth in our end-ofgrade achievement test scores. Our faculty was hardworking and dedicated to the academic growth of students. We all wondered how this could have happened. Our principal told us that something had to change. This coming year had to be different. But neither she nor anyone else in the room had a clear idea of how or what to do. We knew that if we were discouraged as a school improvement team, the rest of our faculty would be discouraged as well. This was not a good way to start the school year.

The conversation and discussion led in a natural direction. We needed to improve our test scores, so obviously we needed to focus on improving academics. Teachers began to discuss the extra programs that we would need to eliminate in order to get "more classroom time." Someone began writing a list of the extra activities to be eliminated to get more academics into the school day: recess, mentoring, yearbook time, English as a Second Language pullout, and, although no one said it, I knew my groups and individual sessions would eventually be on the list. I thought, "Well, I'll do what I need to do to help the school with test scores. Perhaps all my groups would be based solely on academics and study habits this year."

This is the experience of the first author. The initial response to this situation described here may be common in this age of accountability, in which student "growth" is measured primarily, if not exclusively, by standardized tests. The focus of schools has thus become teaching tightly prescribed content knowledge and related skills in order to meet state benchmark standards set for subjects (Scales \& Toccogna, 2000). It seems that if we are focused on test scores as the measure of success then the solution to failure is to address the problem through remediation of selected students (or teachers) and focus more time on teaching the content and skills related to the test. However, there may be other ways to address student growth and promote student achievement.

\section{ANOTHER WAY}

Findings from research conducted through the Search Institute provide a strengths-based conceptual framework for promoting positive development in youth (Scales, 2000). Forty developmental assets have been identified and the number of assets that a youth has is directly related to positive behaviors including success in school (Scales, 2000, 2005). These protective factors that promote success in youth may be both internal (developed by the individual) as well as those that can be developed in the environment (Scales, 2000). With regard to protective factors in the environment, there is an increasing body of research indicating that the number and quality of interactions between adults and students, student feelings of belongingness and of being cared for, and positive interpersonal relationships between teachers and students have been linked to decreases in students' at-risk behavior and, perhaps most importantly, higher levels of emotional well-being, motivation, and academic and social success 
(Brooks, 2006; Gilman, Meyers, \& Perez, 2004; Wentzel, 1997; Wentzel \& Watkins, 2002).

The inception and implementation of the "Connections Through Clubs" program is one example of a school counselor, in collaboration with her colleagues, seizing the opportunity to promote an environment that facilitates academic, career, and personal/social development for all students (American School Counselor Association [ASCA], 2005). School counselors use processes such as individual counseling, group counseling, and advisement to facilitate critical internal protective factors or remediate problems that exist, and they can utilize processes such as coordination, consultation, and collaboration to infuse a larger-scale strengthsbased focus to reverse the trend in which students experience fewer developmental assets as they grow and promote these protective factors in the environment (Scales, 2005). Indeed, there has been an increasing call for a focus on indirect services in order to effectively influence the educational and personal development of all students (Adelman \& Taylor, 2002; Bemak, 2000; Galassi \& Akos, 2004). Through an intertwining of the personal narrative of a professional school counselor, and literature on school climate and developmental assets, the remainder of this article focuses on the implementation and evaluation of the Connections Through Clubs program within the context of a strengthsbased perspective.

\section{CLUB PROGRAM INCEPTION}

promoting positive

development in

youth.

As I continued thinking about eliminating pullouts, I thought about the students who benefited from the small-group opportunities offered through these programs. Specifically, I thought of the students who were referred to me every year for mentoring. My mentoring program always consisted of too many mentees and not enough mentors. Additionally, many of our teachers felt awkward working one on one with students, commenting that they weren't “counselors" and often did not know what to say. I also thought about my students who seemed disconnected from school, from peers, from adults. Every year I had a group of students who would have benefited from the small-group connection and potential for success that extracurricular activities provide but because of finances and transportation issues they could not participate. Finally, I wondered how eliminating pullouts and increasing academic time would affect the teacher burnout I was observing in many of the classrooms. Teachers who had previously loved to teach were now complaining that they were missing out on what they loved most about teaching, which was reaching out to students, connecting with them, and helping them learn. Several teachers shared stories with me of how they used their personal interests and talents to facilitate the teaching process. However, with the current emphasis on content covered by the tests, that type of teaching felt more like a luxury than common practice.

Then it occurred to me that while increasing academic time and focus may be the logical thing to do, maybe it was not the only answer to addressing student achievement. As we were taking a break later that morning, with a few of us in the faculty lounge, I asked, "Does anyone think that this may not be the direction we have to be going?" For the past 2 years, I had been thinking about implementing a club program in which all students would participate in a small group led by a staff member. It would be similar to the advisor-advisee model that used to be in middle schools except that this program would be across grade levels and based on a shared interest. This program would address the mentoring need as well as providing extracurricular opportunities and connections among students and between students and faculty. Now seemed like the time to share this idea, and when I did, this small group of teachers immediately responded with ideas for many different types of clubs. We came back to the meeting with new energy and new ideas and presented the idea to the school improvement team.

Initially, the team was reluctant. One person said, "Time in a club program is just time away from my students and from academics. So how could that possibly help?" And it was during moments like these that I would stop and question the concept myself. It certainly doesn't seem logical, but I thought back to my training and my experience as a professional school counselor. The students with whom I have been most effective have been the ones for whom I could see the whole picture. When a teacher sends me a student because he is doing poorly in math class, the teacher is not expecting or wanting me to give him math tutoring. I have to see the bigger picture and consider all the factors that go into helping students learn. So I continued to respond to questions by reminding teachers of what they already knew to be true. Students learn well because of a variety of influences. Yes, we need to look at our curriculum and instruction, and we also need to look at what else is influencing our students.

All students benefit from supporting and caring relationships with teachers and other adults (Brooks, 2006; Wentzel, 1997). The presence of "other adult relationships" is recognized as a developmental asset linked to facilitating academic and life success (Scales, 2005). Scales suggested that one way to promote this asset is to "create/expand mentoring programs so that every student has at least one building adult with whom he or she has a caring and 
supportive relationship" (p. 109). Additionally, participation in structured extracurricular activities promotes personal/social development and academic achievement (Gilman et al., 2004). Student participation in extracurricular or cocurricular activities of interest also is recognized as a developmental asset promoting constructive use of time (Scales; Scales \& Taccogna, 2000).

\section{CLUB PROGRAM IMPLEMENTATION}

Once the school improvement team formally accepted the club concept, we presented it to the staff at the opening faculty meeting of the year. By that time we had found out officially that our students had met expected growth on our end-of-grade tests. Although the crisis was averted, the club program had gained momentum among faculty and it seemed that this was an opportunity to address broader needs within our school. We decided that clubs would meet every other Friday for 45 minutes from September until spring break. Each faculty member (including our principal and office secretary) designed his or her own club and submitted a club name and description along with a request for materials. The more than 40 clubs varied in content including arts (Jewelry Making, Scrapbook, TV Production), fitness (Swing Dance, Dance Team, Hula Hooping, Ultimate Frisbee), science and problem solving (Chess, Money Makers Club, Virtual Tour of Iceland, Survival Skills), academic (Journalism, Fun With Latin and Greek, Math Club), as well as special topics (Guitar Club, Sign Language, No-Bake Cooking, Junior Optimist, Law Enforcement, ROTC).

The descriptions were compiled in a list for students to view and make a selection of three choices with no rank order, and students were promised one of their three choices. Club leader names were not given to students. At the end of club selection day, I was in my office surrounded by 640 student lists without a plan for how to assign students to their clubs. Thankfully, the technology teacher walked by my door, shook his head, and asked, "Have you thought of using a database?" Within a few days, he had worked with me to develop a database that reduced a task that would have taken days to about 2 hours.

I met with two other members of the school improvement team (an exceptional-child teacher and a music teacher) to discuss ways to solicit parent and community involvement for additional club leaders and financial support. Logistics such as room assignments and dismissal to and from clubs were reviewed by administrators and given to the faculty.

I was talking about clubs all the time to anyone who would listen. A friend who is a counselor edu- cator (the second author) asked me how I was going to measure the impact and effectiveness of clubs. Within a few days she and I had articulated the three overarching goals of the club program: (a) to foster positive personal and supportive connections between teachers (or another caring adult club leader) and students around a mutual interest; (b) to build cooperative and positive connections between peers; and (c) to provide an opportunity for students to explore interests, gain skills, and have fun through a unique learning experience of their choosing. These proximal goals were my first priority for the program, even though I knew achievement would be essential.

There were two stages in the evaluation process during the first year of clubs. Halfway through the year, information was solicited from teachers through a brief, open-ended questionnaire and focus groups conducted by the counselor educator with each "team" of teachers in the school. At that time, teachers were asked to give feedback on their impressions, thoughts, and feelings about the clubs as well as report what they had heard from students about clubs. This feedback ultimately resulted in changes that enhanced the administration of clubs (e.g., dismissal of students, substitutes for absent club leaders).

The second stage occurred at the end of the year. All students and club leaders were asked to complete a survey to assess the degree to which the goals of the program were achieved. Students were asked to indicate their level of agreement on a 5-point scale ranging from 1 for never to 5 for always, with statements reflecting their relationship with their club leader (e.g., "I have a good relationship with my club leader"), their club peers (e.g., "Other students in this club liked/cared about me"), learning new skills ("Because of my participation in clubs, I learned something new"), and their general feelings about clubs ("Participating in clubs was fun for me"). In preliminary results of 548 student responses, $86.7 \%$ indicated that they had learned something new $(M=3.95, S D=1.21)$ and $90.6 \%$ enjoyed clubs $(M=4.23, S D=.87)$. Overwhelmingly students indicated positive relationships with club leaders $(M$ $=4.37, S D=.72)$ and peers $(M=4.37, S D=.84)$.

The survey for club leaders focused on their relationships with their students, their general feelings about clubs, and their focus on teaching and mentoring. With regard to relationships with students, $90 \%$ of the club leaders who completed the survey ( $n=32$ ) were mostly happy with the relationships that were developed with students in their clubs. All club leaders except one indicated that they found club time fun with the majority indicating it was fun most of the time. Teachers indicated a balance between a focus on engaging in a teacher role as dif-

\section{The presence of "other adult relationships" is recognized as a developmental asset linked to facilitating academic and life success.}


ferentiated from a mentoring role. Most club leaders (24) indicated that building a positive mentoring relationship was as important as teaching students new skills. However, answers to a related question revealed that $66 \%(21)$ indicated their role as club leader was similar to a teacher role and $28 \%$ indicated a balance between a teacher and a mentor role. To further illuminate the focus of club leaders, $25 \%$ (8) indicated they focused as much if not more on teaching life and social skills rather than focusing on skills related to the club theme, with $28 \%$ indicating more of a balanced approach and the majority of club leaders (15) focusing on the latter.

Based on our evaluation, the goals articulated for the club program have been met. The facilitation of the relationships between peers, the connections between students and school workers and community members, and the engagement of students in a structured school activity are considered external developmental assets as well as components of school climate (Hernandez \& Seem, 2004; Scales, Benson, Roehlkepartain, Sesma, \& van Dulmen, 2006). Although there have been direct links made between school climate and developmental assets to student achievement (Lehr \& Christenson, 2002; Scales et al.), often there is more of an indirect effect (Lehr \& Christenson). However, there is a consensus emerging that by focusing on improving the learning environment including relationships and involvement, the chances for successful school experiences are improved (Hernandez \& Seem; Lehr \& Christenson; Scales et al.).

The original impetus for the program's development, the concern of the academic achievement of the students, was not able to be directly assessed due to the design of the program. After the first year of club implementation we discovered that we did not meet expected growth on our end-of-grade achievement tests. The fears we had the previous year were realized. We are continually working to make improvements to assist our students in their academic success. The club program is seen as one way to do this. Given all of the recognized benefits of the club program, elimination of the program was never discussed and we continue to make improvements and assess its impact.

\section{ONGOING LEADERSHIP, COLLABORATION, AND ADVOCACY: IMPACTING THE SCHOOL COMMUNITY}

One of the unexpected benefits we discovered in our club program was our ability to use clubs to further enhance connections between parents and our school. For example, during our parent night, we offered some of our most popular clubs so that students could attend clubs (often clubs that they had heard about but were not involved in) while parents attended parent sessions. The result was a dramatic increase in parent attendance. Additionally, we made clubs a featured part of our annual talent show. Those clubs not featured in the talent show created display boards to show what club members had done throughout the year. In this way students could enjoy a culminating event together showcasing their experience and parents could witness firsthand what was happening in the clubs. A few club leaders were asked by parents to meet as part of a school conference because they considered the club leader's insight valuable to their child's school experience.

We have now completed our third year of clubs. Based on the initial and ongoing feedback from teachers and students, we made several changes to the clubs since the first year. One outcome has been an increase in the frequency and duration of clubs. We changed club day from Fridays to Wednesdays so that clubs could be offered more routinely throughout the year (often Fridays are selected as teacher work days or holidays). In addition, we increased club time from 45 minutes to an hour to allow more mentoring time. Another outcome was that the majority of club leaders began to think of their time in the clubs as mentoring opportunities. Club leaders focus more on the process aspect of working with students (e.g., facilitating conversations, fostering relationships between peers) rather than content or the completion of a project. We give club leaders several team-building activities at the beginning of the year to assist them with building student connections. An additional outcome was the increase in community involvement and the financial resources for clubs. Due in large part to donations from community and civic organizations that responded positively to the benefits of the club program, we increased our club budget from $\$ 200$ to almost $\$ 3,000$.

While quantitative academic data may be lacking, I have many stories about students whose lives have been impacted by the clubs. "David" is a student I was working with who seemed to have all the cards stacked against him. He had a difficult home life with little involvement from the grandmother who was raising him. He was chronically picked on because of the way he spoke and looked. He was a special education student who needed a lot of academic and social support from the adults in the school. He frequently cried in school because he didn't have any friends. The teachers worked with him in the classroom to impact his academics and he participated in a weekly social skills group. David told me that every year had been like this for him. He was in my office almost every day for the first three months of school.

One day, I was talking with our teacher who 
worked with the academically gifted students and was the club leader for our "Outdoor Adventurers" club. She said, "I have a student in my club who is such a wonderful leader! He helps me set up for the club. He keeps the other students on task. I want to talk to his teachers about him." I asked who it was. "David," she said. She had no idea of the struggles David was having in school. I realized I was not seeing David in my office as frequently as I had been. His teachers reported to me that he seemed to be making better relationships with peers. When I talked with David and asked him where he felt best, he answered, "In my club."

\section{CONCLUSION}

Although the school counselor may not have intended to assert herself as a leader, advocate, collaborator, and change agent when she asked the question "Does anyone think that this may not be the direction we have to be going?" she took on each of these roles by seizing the opportunity to speak out and offer her expertise. School counselors are called upon to be leaders, advocates, and collaborators in order to move to a central position to support student success (ASCA, 2005; House \& Hays, 2002). Through these "indirect" roles and their understanding of the community, environmental, and institutional opportunities that enhance student success, professional school counselors can impact the school community and make a difference in the lives of all students (House \& Hays).

Sometimes we don't know what intervention will have the most impact on our students. But we can see the bigger picture and we understand the basic needs that we all have and what makes us thrive. We can make a difference when we share our voice and help make the connections.

\section{References}

Adelman, H. S., \& Taylor, L. (2002). School counselors and school reform: New directions. Professional School Counseling, 5, 235-248.

American School Counselor Association. (2005). The ASCA national model: $A$ framework for school counseling programs (2nd ed.). Alexandria, VA: Author.
Bemak, F. (2000). Transforming the role of the counselor to provide leadership in educational reform through collaboration. Professional School Counseling, 3, 322-331.

Brooks, J. E. (2006). Strengthening resilience in children and youths: Maximizing opportunities through schools. Children \& Schools, 28, 69-76.

Galassi, J. P., \& Akos, P. (2004). Developmental advocacy: Twenty-first century school counseling. Journal of Counseling \& Development, 82, 146-157.

Gilman, R., Meyers, J., \& Perez, L. (2004). Structured extracurricular activities among adolescents: Findings and implications for school psychologists. Psychology in the Schools, 41, 31-41.

Hernandez, T. J., \& Seem, S. R. (2004). A safe school climate: A systemic approach and the school counselor. Professional School Counseling, 7, 256-262.

House, R. M., \& Hays, R. L. (2002). School counselors: Becoming key players in school reform. Professional School Counseling, 5, 249-256.

Lehr, C. A., \& Christenson, S. L. (2002). Best practices in promoting a positive school climate. In A. Thomas \& J. Grimes (Eds.), Best practices in school psychology IV: Vol. 2 (pp. 977-991). Bethesda, MD: National Association of School Psychologists Publications.

Scales, P. C. (2000). Building students' developmental assets to promote health and school success. The Clearing House, 74(2), 84-88.

Scales, P. C. (2005). Developmental assets and the middle school counselor. Professional School Counseling, 9, 104-111.

Scales, P. C., Benson, P. L., Roehlkepartain, E. C., Sesma, A., Jr., \& van Dulmen, M. (2006). The role of developmental assets in predicting academic achievement: A longitudinal study. Journal of Adolescents, 29, 691-708.

Scales, P. C., \& Taccogna, J. (2000). Caring to try: How building students' developmental assets can promote school engagement and success. NASSP Bulletin, 84, 69-78.

Wentzel, K. R. (1997). Student motivation in middle school: The role of perceived pedagogical caring. Journal of Educational Psychology, 89, 411-419.

Wentzel, K. R., \& Watkins, D. E. (2002). Peer relationships and collaborative learning as contexts for academic enablers. School Psychology Review, 31, 366-377.

\section{Earn CEUs for reading this article. Visit www.schoolcounselor.org, and click on Professional School Counseling to learn how.}

School counselors are called upon to

be leaders, advocates, and collaborators in order to move to a central position to support student 